\title{
PENAMPILAN REPRODUKSI SAPI PERANAKAN ONGOLE (PO) DI KECAMATAN DUMOGA KABUPATEN BOLAANG MONGONDOW
}

\author{
Jeilin Kristahun, Endang Pudjihastuti, Umar Paputungan, Santie Turangan
}

Fakultas Peternakan Universitas Sam Ratulangi Manado, 95115

\begin{abstract}
ABSTRAK
Penelitian telah dilakukan untuk mengetahui keadaan reproduksi ternak sapi Peranakan Ongole (PO) di Kecamatan Dumoga Kabupaten Bolaang Mongondow. Materi yang digunakan dalam penelitian ini adalah ternak sapi PO milik petani peternak yang diambil secara sampel. Pemilihan sampel desa ditentukan secara sengaja (purposive) dengan pertimbangan desa yang memiliki populasi terbanyak yaitu desa Toruakat, desa Pusian dan desa Siniung. Pemilihan responden menggunakan metode random samping yaitu mengambil 25 peternak dari masingmasing desa terpilih sehingga mendapatkan 75 peternak. Analisis data mengenai variabel yang diteliti menggunakan analisis deskriptif dengan mengacu pada model pengukuran setiap variabel menunjukkan bahwa penampilan reproduksi ternak sapi Peranakan Ongole (PO) di Kecamatan Dumoga khususnya di Desa Toruakat, Pusian dan Siniyung sudah tergolong sangat baik karena Conception Rate di desa Toruakat $90 \pm 30,304$, desa Pusian $78 \pm$ 41,845 dan desa Siniyung $86 \pm 35,051$ ini menunjukan bahwa desa Toruakat dan Pusian memiliki angka yang signifikan sedangkan Service per Conception desa Toruakat 1,12 $\pm 0,385$, desa Pusian 1,24 \pm 0,476 dan desa Siniyung 1,22 $\pm 0,582$ dan Calving Interval desa Toruakat 360,7 \pm 3.914, desa Pusian 360,4 \pm 3.620 dan Siniyung $362,4 \pm 3.232$ hasil pengamatan menunjukan angka Service per Conception
\end{abstract}

*Korespondensi (corresponding author): Email: endangpudjihastuti@unsrat.ac.id dan Calving Interval non signifikan. Berdasarkan hasil penelitian dapat disimpulkan bahwa penampilan reproduksi ternak sapi Peranakan Ongole (PO) di Kecamatan Dumoga khususnya di Desa Toruakat, Pusian dan Siniyung sudah tergolong sangat baik.

\section{Kata Kunci: Penampilan, Sapi Peranakan Ongole (PO)}

\section{ABSTRACT}

Research has been conducted to determine the reproductive condition of Ongole Cross-breed cattle (PO) in Dumoga District, Bolaang Mongondow Regency. The material used in this study is the farmer-farmer's PO cattle taken by sample. .Village sample selection is determined purposively (purposive) with the consideration that the villages that have the largest population are Toruakat village, Pusian village and Siniung village. The selection of respondents used a side random method, namely taking 25 breeders from each of the selected villages to get 75 breeders. data analysis regarding the variables studied using descriptive analysis with reference to the measurement model of each variable showed that the reproductive performance of Ongole Cross-breed cattle (PO) in Dumoga District, especially in the Villages of Toruakat, Pusian and Siniyung, is classified as very good because the Conception Rate at Toruakat village $90 \pm$ 30.304, Pusian village $78 \pm 41.845$ and Siniyung village $86 \pm 35.051$ showed that Toruakat and Pusian villages have significant numbers while Service per 
Conception in Toruakat village is $1.12 \pm$ 0.385 , Pusian village is $1.24 \pm 0.476$ andSiniyung Village $1.22 \pm 0.582$ and Toruakat Village Calving Interval $360.7 \pm$ 3.914, Pusian Village $360.4 \pm 3.620$ and Siniyung $362.4 \pm 3,232$ the results of observations showed that the Service per Conception and Calving Interval numbers were not significant. it can be concluded that the appearance of PO cattle reproduction in Dumoga District especially in Toruakat village, Pusian village and Siniyung village has been classified as very good.

\section{Keywords: Appearance, Ongole Cattle (PO)}

\section{PENDAHULUAN}

Sapi potong merupakan ternak penghasil daging dan merupakan sumber protein hewani yang bergizi tinggi. Konsumsi daging dapat selalu meningkat seiring dengan bertambahnya populasi penduduk di Indonesia. Upaya peningkatan populasi sapi potong dapat dilakukan dengan berbagai cara diantaranya adalah meningkatkan mutu genetik dan efisiensi reproduksi (Susilawati, 2011).

Masalah ketersediaan daging terutama daging sapi potong, meskipun ketersedian ternak sapi cukup, namun belum dapat memenuhi permintaan masyarakat terutama di hari-hari besar keagamaan. Ada beberapa faktor sehingga ketersediaan daging sapi belum maksimal diantaranya adalah masalah rendahnya produktifitas ternak sapi potong di
Indonesia (rendahnya tingkat kelahiran, lambat beranak, jarak beranak panjang, tingkat kematian pedet tinggi dan perbaikan genetik lambat.

Secara nasional, kebutuhan sapi potong untuk memenuhi konsumsi daging sapi di Indonesia setiap tahun selalu meningkat., sejalan dengan bertambahnya jumlah penduduk, peningkatan pendapatan dan kesejahteraan masyarakat serta semakin tingginya tingkat kesadaran masyarakat akan pentingnya protein hewani. Dipihak lain, kemampuan penyediaannya berkembang lebih rendah dari pada laju permintaannya. Dengan demikian impor bakalan daging terus menunjukkan berbagai upaya yang mampu menopang produktivitas, khususnya pada peternakan sapi potong rakyat yang masih terbatas. Fenomena ini menjadi tantangan besar bagi para peternak untuk selalu berupaya memenuhinya sehingga pada saat ini banyak muncul kegiatan agribisnis peternakan sapi potong dan keja, termasuk peternak sapi potong yang ada di Kecamatan Dumoga, Kabupaten Bolaang Mongondow.

Produksi ternak akan baik bila proses reproduksi berjalan dengan normal. Pada hakikatnya produksi di bidang peternakan hanya dapat diperoleh bila ada proses reproduksi. Efisiensi reproduksi yang tinggi dengan produktivitas ternak yang tinggi dapat diperoleh bila 
kemampuan reproduksi kelompok ternak tinggi disertai dengan pengelolaan ternak yang baik (Priyanto, 2016).

Kabupaten Bolaang Mongondow khususnya di Kecamatan Dumoga memiliki sumber daya alam yang tersedia yang memungkinkan dikembangkan usaha peternakan termasuk ternak sapi potong. Di daerah ini sangat potensial untuk pengembangan ternak sapi potong terutama untuk memenuhi kebutuhan daging asal ternak. Sehubungan dengan adanya upaya pengembangan ternak sapi potong ini, maka hal teknis dalam manajemen pemeliharaan ternak seperti penanganan reproduksi penting untuk diketahui karena sangat berpengaruh terhadap produktivitas ternak yang dibudidayakan.

Menurut Iskandar (2011) bahwa beberapa hal terkait yang mempengaruhi tinggi rendahnya reproduksi ternak diantaranya yaitu: jumlah perkawinan yang dibutuhkan oleh betina sampai menghasilkan kebuntingan (Service per Conception), jarak antar kelahiran (calving interval) dan persentase angka ternak betina yang bunting pada perkawinan pertama (Conception Rate).

Sehubungan dengan pentingnya informasi mengenai hal-hal yang sifatnya teknis dalam sistem reproduksi pada ternak sapi potong ini serta belum tersedianya informasi, maka penelitian ini dilaksanakan guna mengetahui keadaan reproduksi ternak sapi potong di Kecamatan Dumoga, Kabupaten Bolaang Mongondow karena hal ini sangat menentukan produktivitas ternak terutama dalam peningkatan populasi serta adanya ketersediaan daging.

\section{MATERI DAN METODE PENELITIAN}

Materi yang digunakan dalam penelitian ini adalah sapi PO milik petani peternak yang diambil secara sampel di beberapa wilayah Kecamatan Dumoga, Kabupaten Bolaang Mongondow. Pemilihan sampel desa ditentukan secara sengaja (purposive) dengan pertimbangan tertentu (Sugiyono, 2010) yaitu desa yang memiliki ternak sapi PO terbanyak yaitu Desa Toruakat, Pusian, dan Desa Siniyung. Pemilihan responden peternak sapi potong menggunakan metode random sampling karena pengambilan sampel anggota populasi dilakukan secara acak tanpa memperhatikan strata dalam populasi (Sugiyono, 2010), yaitu mengambil 25 peternak yang ada di masing-masing desa terpilih dan untuk sampel ternak yang akan diteliti yaitu ternak sapi PO yang dipelihara oleh 25 peternak di masing-masing Desa terpilih.

Metode penelitian yang digunakan adalah metode survei dan pengumpulan data dilakukan dengan cara pengisian daftar kuisoner melalui wawancara terhadap 
responden peternak sapi serta pengamatan langsung di lapangan. Data yang dikumpulkan berupa data primer dan data sekunder.

Variabel penelitian yang diteliti adalah :

1 Service per Conception (S/C) adalah jumlah ternak yang kawin yang diperlukan untuk menghasilkan kebuntingan.

2 Conception Rate (CR)

Conception rate (CR) adalah jumlah betina kawin pertama yang positif bunting dibagi jumlah betina yang dikawinkan dikali $100 \%$

3 Calving Interval (CI) adalah selang waktu dari beranak sampai beranak berikutnya (hari).

Analisis data yang digunakan dalam penelitian ini adalah analisis deskriptif dengan mengacu pada model sebagai berikut :

\section{Service per Conception (S/C)}

$$
S C=\frac{\text { Jumlah perkawinan }}{\text { Jumlah betina bunting }}
$$

\section{Conception Rate (CR)}

$C R$

$=\frac{\text { Jumlah betina yang kawin pertama }}{\text { Jumlah seluruh betina yang kawin }} \times 100 \%$

3. Calving Interval (CI)

Perhitungan nilai CI menurut Ball dan Peters (2004), yaitu dengan menggunakan rumus sebagai berikut :
Calving Interval (bulan) = waktu kelahiran ke-i - waktu kelahiran ke (i-1). CI $($ hari $)=$ periode kebuntingan $(\mathrm{X} 1)+$ periode lama masa kosong pada layanan pertama setelah melahirkan (X2). Periode kebuntingan (X1) sekitar kurang lebih 280 hari. Periode masa kosong pada layanan pertama terdiri dari suckling age (umur menyusui anak) sebelum terjadi konsepsi berikutnya adalah X2 (hari).

\section{HASIL DAN PEMBAHASAN}

\section{Gambaran Umum Lokasi Penelitian}

Kecamatan Dumoga yang berbatasan langsung dengan Taman Nasional Bogani Nani Wartabone (TNBNW; sebelumnya bernama Taman Nasional Dumoga Bone) sejak dulu sudah dikenal sebagai wilayah pertambangan emas, dengan batas geografis yakni sebelah utara dengan Kecamatan Dumoga Timur, sebelah selatan dengan Kecamatan Pinolosian dan sebelah timur dengan Kecamatan Lolayan.

Topografi Dumoga beragam mulai dari dataran landai sampai bergunung dengan ketinggian tempat $150 \mathrm{~m}$ dpl (meter diatas permukaan laut) yang diukur dari ibukota kecamatan. Desa yang terletak di perbukitan adalah desa Serasi dan Kanaan dengan ketinggian $480 \mathrm{~m}$ dan $800 \mathrm{~m}$ dpl. Secara umum curah hujan setiap tahunnya rata-rata $180,97 \mathrm{~mm} /$ tahun dengan wilayah 
yang tidak berbatasan langsung dengan pantai. Luas wilayah Desa di Kecamatan Dumoga yaitu Desa Toruakat 41,20, Kanaan 6,46, Pusian 42,20, Ponompiaan 37,27, Mototabian 36,00, Serasi 12,71, Bumbungon 38,68, Siniyung 45,95, Dumoga I 23,77 (BPS, 2017).

\section{Identitas Responden}

Identitas responden merupakan salah satu indikasi yang dapat digunakan untuk mengetahui kemampuan dalam mengelola ternak antara lain umur peternak, mata pecaharian, tingkat pendidikan dan lama beternak (Sumadi et al., 2011).

\section{Umur}

Umur merupakan salah satu faktor yang mempengaruhi produktivitas kerja seseorang. Presentase umur seseorang akan berpengaruh terhadap kemampuan dalam mengerjakan pekerjaan. Seiring bertambahnya umur maka akan mempengaruhi kemampuan fisik, sehinga terjadi penurunan produktivitas. Makatita (2013) mengemukakan bahwa banyaknya peternak yang berada pada kelompok umur produktif merupakan modal utama dalam pengembangan suatu usaha peternakan. Umur peternak yang lebih dari 45 sampai 55 tahun merupakan umur yang cukup produktif (Supartini dan Darmawan, 2014). Adapun distribusi responden dilokasi penelitian menurut umur disajikan dalam Tabel 1. Hasil penelitian menunjukan bahwa kisaran umur peternak cukup bervariasi yaitu antara 30 sampai 67 tahun. Berdasarkan data pada Tabel 1 bahwa distribusi responden yang berumur dibawah 40 tahun sebanyak 19 peternak $(25,33 \%)$, responden yang berumur antara 40 sampai 50 tahun sebanyak 26 peternak (36\%), dan responden yang berumur lebih dari 60 tahun sebanyak 29 peternak $(38,67 \%)$. Hal ini berarti bahwa peternak di lokasi penelitian sebagian besar dalam kategori produktif dan sebagian kecil berada dalam kategori non produktif.

\section{Tingkat Pendidikan}

Tingkat pendidikan responden dilokasi penelitian yaitu di desa Toruakat, Pusian dan desa Siniung cukup bervariasi. Tinggi rendahnya tingkat pendidikan peternak sangat mempengaruhi informasi yang

Tabel 1. Distribusi Responden Menurut Umur

\begin{tabular}{llll}
\hline No. & Umur & Jumlah Responden & Persentase (\%) \\
\hline 1. & $<40$ & 19 & 25,33 \\
2. & $41-50$ & 27 & 36 \\
3. & $>50$ & 29 & 38,67 \\
\hline Total & & $\mathbf{7 5}$ & $\mathbf{1 0 0}$ \\
\hline
\end{tabular}


masuk, tingkat pengetahuan, keterampilan, dan sikap peternak dalam kegiatan usahanya, sehingga dalam pelaksanaannya para peternak selain mengandalkan pengalaman yang ada, juga mampu mempelajari ilmu pengetahuan yang terus berkembang dalam dunia peternakan sapi potong.

Hasil penelitian menunjukan bahwa sebagian besar peternak yaitu lulusan sekolah dasar (SD) sebanyak 37 orang $(49,33 \%)$, lulusan sekolah menengah pertama (SMP) sebanyak 26 orang $(34,67 \%)$, dan sekolah menengah atas (SMA/Sederajat) sebanyak 10 orang $(13,33 \%)$, dan lulusan strata satu (S1) sebanyak dua orang (2,67\%). Komposisi pendidikan tertinggi para peternak adalah sekolah dasar (SD) yaitu sebesar 37 orang $(49,33 \%)$. Tingkat pendidikan para peternak masih tergolong rendah, hal ini akan berpengaruh terhadap cara mereka beternak. Tingkat pendidikan sangat berpengaruh terhadap pengelolaan peternakan, karena semakin tinggi pendidikan seseorang akan lebih mudah dalam menerima teknologi baru (Lestari, 2000). Pendidikan dapat memberikan pemahaman yang lebih baik bagi petani tentang permasalahan yang dihadapi dan kemudian memikirkan solusinya (Van den Ban dan Hawkins, 1996).

\section{Jumlah Kepemilikan Ternak}

Klasifikasi kepemilikian ternak yang dipelihara oleh responden di lokasi penelitian disajikan dalam Tabel 3.

Tabel 2. Distribusi Responden Menurut Tingkat Pendidikan

\begin{tabular}{llll}
\hline No. & Tingkat Pendidikan & Jumlah Responden & Persentase (\%) \\
\hline 1. & SD & 37 & 49,33 \\
2. & SMP & 26 & 34,67 \\
3. & SMA/Sederajat & 10 & 13,33 \\
4. & S1 & 2 & 2,67 \\
\hline Total & & $\mathbf{7 5}$ & $\mathbf{1 0 0}$ \\
\hline
\end{tabular}

Tabel 3. Klasifikasi Berdasarkan Jumlah Kepemilikan Ternak

\begin{tabular}{llll}
\hline No. & Jumlah Kepemilikan & Jumlah Responden & Persentase (\%) \\
\hline 1. & $2-5$ & 53 & 70,67 \\
2. & $6-10$ & 22 & 29,33 \\
\hline Total & & $\mathbf{7 5}$ & $\mathbf{1 0 0}$ \\
\hline
\end{tabular}


Berdasarkan hasil penelitian bahwa sebagian besar $(70,67 \%)$ peternak di lokasi penelitian memiliki ternak berkisar dua sampai lima ekor dan sebagian kecil $(29,33 \%)$ peternak memiliki ternak berkisar lebih dari enam ekor. Menurut Bessant (2005), skala kepemilikian ternak sapi potong oleh peternak yang bersifat sebagai peternakan rakyat di kelompokkan menjadi tiga bagian yaitu skala kecil satu sampai lima ekor, enam sampai sepuluh ekor dan lebih dari sepuluh ekor.

\section{Penampilan Reproduksi Ternak Sapi Peranakan Ongole}

Latar belakang peternak yaitu meliputi lama beternak, tingkat pendidikan, motif pemeliharaan dan tujuan pemeliharaan ternak turut mempengaruhi manajemen pemeliharaan sapi, yang pada akhirnya dapat mempengaruhi penampilan reproduksi sapi.

\section{Service per Conception (S/C)}

Service per Conception (S/C) merupakan jumlah perkawinan yang digunakan untuk memperoleh kebuntingan atau konsepsi (Susilawati, 2011). Service Per Conception pada sapi PO di masingmasing desa dapat dilihat pada Tabel 4 . Tabel 4 menunjukan bahwa S/C di Desa Siniyung dan desa Pusian masih lebih baik dari Desa Toruakat. Namun nilai S/C di ketiga desa lokasi penelitian relative sama dengan berbeda tidak nyata berdasarkan uji $\mathrm{t}$ serta lebih rendah yang menunjukkan lebih baik dibandingkan dengan hasil penelitian Supriyadi (2010) bahwa S/C 1,44 kali. Nuryadi dan Wahjuningsi (2011) menyatakan bahwa S/C sapi Peranakan Ongole di Kabupaten Malang mencapai 1,28. Didalam penelitian Ihsan (2011) menyatakan bahwa $\mathrm{S} / \mathrm{C}$ sapi hasil silangan berkecenderungan naik seperti sapi Peranakan Ongole sebesar 1,28. Jainudeen dan Hafes (2008) menyatakan bahwa kisaran normal nilai S/C adalah 1,6-2,0. S/C dalam penelitian ini diukur berdasarkan perkawinan secara alami atau kawin alam. Ditambahkan oleh Murni (2015) menyatakan bahwa nilai S/C dikatakan normal antara 1,6-2,0. Ditambahkan oleh Rasad (2009) bahwa

Tabel 4. Perhitungan rataan nilai Service per Conception (S/C) pada Desa Toruakat, Desa Pusian dan Desa Siniyung

\begin{tabular}{lll}
\hline No. & Desa & Rataan S/C (kali) dan Standar Deviasi \\
\hline 1. & Toruakat & $1,12 \pm 0,385$ \\
2. & Pusian & $1,24 \pm 0,476$ \\
3. & Siniyung & $1,22 \pm 0,582$ \\
\hline
\end{tabular}


idealnya seekor sapi betina yang harus mengalami kebuntingan setelah melakukan layanan 1-2 kali selama proses perkawinan.

Hasil penelitian ini menunjukan bahwa semakin rendah nilai $\mathrm{S} / \mathrm{C}$ maka semakin tinggi kesuburan ternak tersebut, yang berarti bahwa S/C ternak sapi peranakan ongole (PO) di Kecamatan Dumoga sudah sangat baik. Hal tersebut selain disebabkan oleh kualitas pejantan yang baik dalam perkawinan, rendahnya nilai S/C dilokasi penelitian terjadi akibat adanya perbedaan lingkungan dan menunjukkan adanya upaya perbaikan serta peningkatan manajemen ketika ternak sapi mengalami birahi pertama dan umur yang tepat untuk perkawinian yang diberikan, serta peternak di lokasi penelitian ini cukup mampu dalam mendeteksi siklus birahi ternak dengan tepat (Siagarini, 2015).

\section{Conception Rate}

Conception Rate / angka konsepsi adalah jumlah ternak yang bunting pada perkawinan pertama (Susilawati, 2005).
Nilai Conception Rate hasil penelitian dapat dilihat pada Tabel 5. Hasil pengamatan rata-rata $\mathrm{CR}$ ternak sapi di desa Toruakat dan desa Siniyung adalah masingmasing $90 \%$ dan $86 \%$ hari dan menujukkan angka yang berbeda tidak nyata $(\mathrm{P}>0,05)$ melalui uji t. Sedang hasil pengamatan ratarata CR ternak sapi di desa Pusian adalah $78 \%$ dan menunjukkan angka yang sangat nyata lebih rendah $(\mathrm{P}>0.05)$ melalui uji $\mathrm{t}$ dibandingkan dengan rata rata $\mathrm{CR}$ di desa Toruakat dan desa Siniyung. Kondisi ini menunjukkan bahwa ternak sapi milik peternak di desa Toruakat dan desa Siniung menunjukkan manajemen reproduksi sapi lebih efisien dibandingkan manajemen reproduksi ternak sapi oleh peternak di desa Pusian.

Nilai Conception Rate sapi PO di Kecamatan Dumoga Kabupaten Bolaang Mongondow lebih tinggi dibandingkan hasil penelitian Nuryadi dan Wahjuningsih (2011) di Kabupaten Malang yaitu Conception Rate sapi PO 75,34\%.

Tabel 5. Perhitungan rataan nilai Conception Rate (CR) pada Desa Toruakat, Desa Pusian dan Desa Siniyung

\begin{tabular}{lll}
\hline No. & Desa & Rataan CR $(\boldsymbol{\%})$ dan Standar Deviasi \\
\hline 1. & Toruakat & $90 \pm 30,304^{\mathrm{a}}$ \\
2. & Pusian & $78 \pm 41,845^{\mathrm{b}}$ \\
3. & Siniyung & $86 \pm 35,051^{\mathrm{ab}}$ \\
\hline
\end{tabular}

Sumber : Superskrip $(\mathrm{a}, \mathrm{b})$ yang berbeda pada kolom yang sama menunjukkan berbeda nyata $(\mathrm{P}<0,05)$ melalui uji t. 
Tabel 6. Perhitungan rataan Calving Interval (CI) pada Desa Toruakat, Desa Pusian dan Desa Siniyung

\begin{tabular}{lll}
\hline No. & Desa & Rataan CI dan Standar Deviasi \\
\hline 1. & Toruakat & $360,7 \pm 3.914^{\mathbf{a}}$ \\
2. & Pusian & $360,4 \pm 3.620^{\mathbf{a}}$ \\
3. & Siniyung & $362,4 \pm 3.232^{\mathbf{b}}$ \\
\hline
\end{tabular}

Keterangan: Supersrcip (a, b) yang berbeda pada kolom yang sama menunjukkan berbeda sangat nyata $(\mathrm{P}<0,01)$ melalui uji t.

Ditambah oleh Fanani (2013) bahwa nilai Conception Rate yang baik mencapai $60 \%-$ $70 \%$. sedangkan yang dapat dimaklumi untuk ukuran Indonesia dengan mempertimbangkan kondisi alam, manajemen dan distribusi ternak yang menyebar sudah dianggap baik jika nilai Conception Rate mencapai 45\%-50\% (Kasim et al., 2010).

\section{Calving Interval (CI)}

Calving Interval (CI) adalah jangka waktu yang dihitung dari tanggal seekor sapi beranak sampai beranak kembali atau jarak beranak dari anak satu ke anak berikutnya. Nuryadi dan Wahjuningsih (2011) menyatakan bahwa CI ditentukan oleh lama bunting dan lama masa kosong (Day Open), sehingga semakin panjang masa kosong (DO) maka nilai CI juga akan semakin besar. Nilai CI ternak sapi PO dilokasi penelitian masing-masing Desa Toruakat, Desa Pusian dan Desa Siniyung disajikan dalam Tabel 6 . Hasil pengamatan rata-rata CI ternak sapi di desa Toruakat dan desa Pusian adalah masing-masing
360,7 hari dan 360,4 hari dan menujukkan angka yang berbeda tidak nyata $(\mathrm{P}>0,05)$ melalui uji t. Sedang hasil pengamatan ratarata CI ternak sapi di desa Siniyung adalah 362,4 hari dan menunjukkan angka yang sangat nyata lebih tinggi $(\mathrm{P}<0.01)$ melalui uji t dibandingkan dengan rata rata CI di desa Toruakat dan desa Pusian. Kondisi ini menunjukkan bahwa ternak sapi milik peternak di desa Toruakat dan desa Pusian menunjukkan manajemen reproduksi sapi lebih efisien dibandingkan manajemen reproduksi ternak sapi oleh peternak di desa Siniyung.

Calving Interval (CI) dapat dipakai sebagai ukuran efisiensi reproduksi, sehingga CI yang ideal berkisar 12-15 bulan atau berkisar 365-455 hari, dimana adanya CI yang panjang dapat disebabkan oleh faktor manajemen yaitu kesengajaan menunda kebuntingan atau karena faktor genetik (Selow, 2009). Dengan demikian, CI di ketiga desa Toruakat, Pusiam dan Siniyung yang mewakili manajemen reproduksi ternak sapi di kecamatan Dumoga kabupaten Bolaang Mongondow 
termasuk dalam kategori masih sangat ideal dan baik.

\section{KESIMPULAN}

Berdasarkan hasil penelitian yang dilakukan dapat disimpulkan bahwa penampilan reproduksi ternak sapi Peranakan Ongole (PO) di Kecamatan Dumoga khususnya di Desa Toruakat, Pusian dan Siniyung sudah tergolong sangat baik.

\section{DAFTAR PUSTAKA}

Badan Pusat Statistik. 2017. Statistik Daerah Kecamatan Dumoga: Badan Pusat Statistik Kabupaten Bolaang Mongondow.

Ball, H. \& A. R. Peters. 2004. Reproduction in Cattle. 3rd Ed. Blackwell Publishing Ltd., Oxford

Bessant, W. 2005. Analisis Usaha Peternakan Sapi Potong Dalam Kaitannya dengan Kesejahteraan Peternak di Kabupaten dan Kota Bogor. Skripsi. Program Persetujuan Manajemen dan Bisnis IPB, Bogor.

Fanani, S. 2013. Kinerja Reproduksi Sapi Peranakan Friesian holstein (PFH) di Kecamatan Pudak, Kabupaten Ponorogo. Prosiding. Fakultas Pertanian Universitas Sebelas Maret. Surakarta.

Ihsan, M.N. dan S. Wahjuningsih. 2011. Penampilan Reproduksi Sapi Potong Di Kabupaten Bojonegoro. TERNAK TROPIKA Journal of
Tropical Animal Production 12(2): 74-80.

Iskandar. 2011. Performan reproduksi sapi po pada dataran rendah dan dataran tinggi di Provinsi jambi. Jurnal Ilmiah Ilmu-Ilmu Peternakan, 14(1): 51-61.

Jainudeen, M. R. and E. S. E,. Hafez. 2008. Cattle and buffalo, Dalam Reproduction in farm animals. 7 th Edition. Edited by Hafez E. S. E. Lippincott Williams \& Wilkins. Maryland. USA. $159: 171$.

Kasim, K., S. Sagaf, A. B. Languha, dan A. D. Malewa. 2010. Analisis produktivitas sapi betina induk di Sulawesi Tengah. Jurnal Ilmu-Ilmu Pertanian 17(1): 70-76.

Lestari, S. K. 2000. Analisis Investasi Usaha Tani Ternak Sapi Potong Yang Tergabung Dalam Kandang Kelompok. Skripsi. Universitas Gadjah Mada, Yogyakarta.

Makatita, J. 2013. Hubungan antara karakteristik peternak dengan skala usaha pada usaha peternakan kambing di Kecamatan Leihitu Kabupaten Maluku Tengah. Jurnal Agrinimal 3(2): 78-83.

Murni, R. 2015. Pelatihan pembuatan lamtoro mineral blok pada peternak rakyat di Desa Pematang Gajah Kabupaten Muaro Jambi. Jurnal Pengabdian pada Masyarakat 30(4): 49-54.

Nuryadi, N. dan S. Wahjuningsih. 2011. Penampilan produksi sapi Peranakan Ongole dan Peranakan Limousin Di Kabupaten Malang. TERNAK TROPIKA Journal of Tropical Animal Production 12(1): 76-81. 
Priyanto, D. 2016. Strategi pengembangan usaha ternak sapi potong dalam mendukung program swasembada daging sapi dan kerbau tahun 2014. Jurnal Litbang Pertanian, 30(3): 108116.

Rasad, S.D. 2009. Evaluasi Penampilan Reproduksi Sapi Perah (Studi Kasus di Perusahaan Peternakan Sapi Perah KUD Sinarjaya). Jurnal Agripet 9(1): 43-49.

Selow, A. 2009. Calving Interval. Avalaible At http://akhirman.blogspot.com/2009 /10/skripsi-contoh-tinjauanpustaka.html.

Siagarini, V. D. 2015. Service per conception $(\mathrm{S} / \mathrm{C})$ dan conception rate (CR) sapi peranakan simmental pada paritas yang berbeda di Kecamatan Sanankulon Kabupaten Blitar. Disertasi. Universitas Brawijaya, Malang.

Sugiyono, (2010). Metode Penelitian Kuantitatif, Kualitatif, dan R\&D. Alfabeta. Bandung.

Sumadi, H.M., T. Hertatik, dan R. D. Mundingsari. 2011. Estimasi potensi pembibitan sapi potong di Kecamatan Wonosari Kabupaten Gunung Kidul Daerah Istimewa Yogyakarta. Laporan Hibah penelitian Tematik Labolatorium. Fakultas Peternakan. Universitas Gadjah Mada, Yogyakarta.
Supartini, N. dan H. Darmawan. 2014. Profil genetik dan peternak sapi peranakan ongole sebagai strategi dasar pengembangan desa pusat bibit ternak. Buana Sains 14(1): 7184.

Supriyadi, W. 2010. Penampilan Reproduksi Ternak Sapi Potong Betina di Daerah Istimewa Yogyakarta. Prosiding. Seminar Nasional Teknologi Peternakan dan Veteriner. Balai Pengkajian Teknologi Pertanian Yogyakarta. Hal : 64-67.

Susilawati, T. 2011. Tingkat keberhasilan inseminasi buatan dengan kualitas dan deposisi semen yang berbeda pada sapi Peranakan Ongole. TERNAK TROPIKA Journal of Tropical Animal Production 12(2): 15-24.

Van den Ban, A. W. And H. S Hawkins. 1996. Agricultural Extension 2nd edn. Blackwell Science, Oxford. 